ppi $201502 Z U 4645$

Esta publicación cientifica en formato digital es continuidad de la revista impresa ISSN-Versión Impresa 0798-1406 / ISSN-Versión on line 2542-3185Depósito legal pp

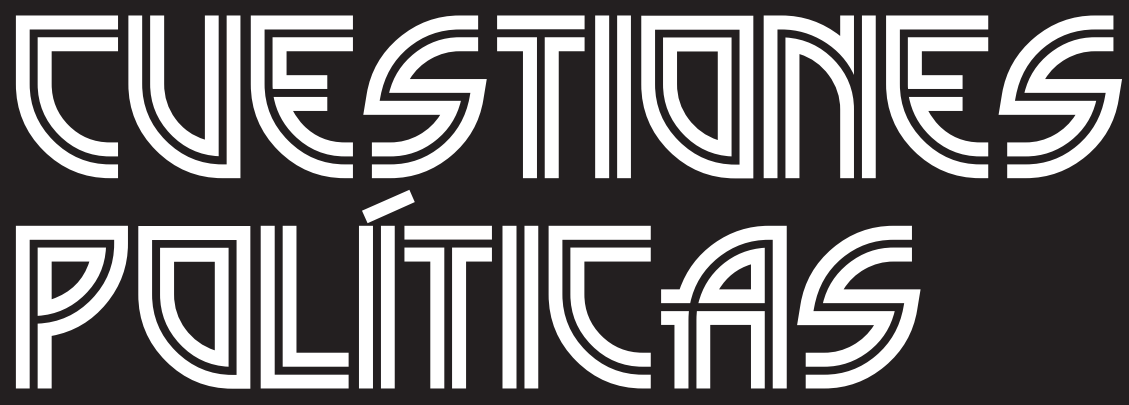

Instituto de Estudios Políticos y Derecho Público "Dr. Humberto J. La Roche' de la Facultad de Ciencias Jurídicas y Políticas de la Universidad del Zulia Maracaibo, Venezuela
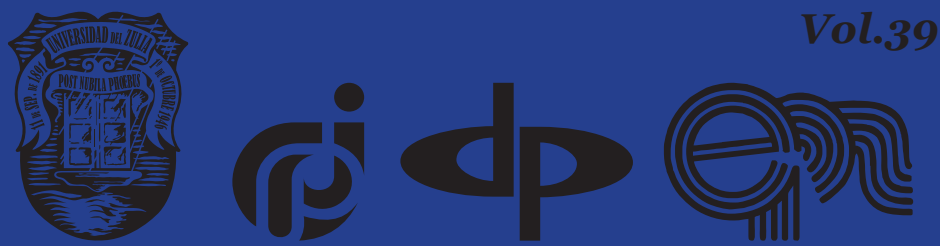


\title{
Diversification Rate of Energy Balance and Energy Export Demand Risk Impacts on Economic Growth: The Case of Azerbaijan
}

\author{
DOI: https://doi.org/10.46398/cuestpol.3968.18
}

\author{
Shahin V. Bayramov ${ }^{*}$ \\ Gulsura Y. Mehdiyeva ${ }^{2 * *}$ \\ Agil A. Eyvazov ${ }^{* * *}$ \\ Elchin R. Mustafayev ${ }^{4 * * *}$
}

\section{Abstract}

The objective of the article was to examine the level of diversification of the energy balance and energy export demand, as well as its impacts on economic growth to ensure energy security in Azerbaijan. Forthe research, the Risk Energy Export Demand Index and its four sub-indexes, i.e.,1) export dependence, were used; 2) risk of monopsonium; (3) the risk of transaction costs; 4) Comparative quantitative assessment of the economic importance of different types of energy in the country's energy exports. The Herfindahl-Hirschman index and the Shannon-Wiener index were used for the assessment of the diversification and concentration rate. The OLS method, the ADF test and cointegration were used to assess the relationship between indicators. It is concluded that the share ofenergy obtained from renewable sources in the country's energy balance is very low (about $3 \%$ ), and the energy obtained from these sources is mainly used for electricity production. Since an essential part of the country's energy balance is in hydrocarbon reserves, the level of diversification is low.

Keywords: energy balance; renewable energy sources; energy security; risk of demand for energy exports; Azerbaijan.

* PhD, associate professor, Mingachevir State University, Azerbaijan. ORCID ID: https://orcid. org/oooo-0002-1720-606X. Email: sh.bayramov@gmail.com

** PhD, associate professor, Institute of Economics of Azerbaijan National Academy of Sciences, ORCID ID: https://orcid.org/oooo-0oo2-8016-9548. Email: gulsura@list.ru

*** PhD, associate professor, Institute of Economics of Azerbaijan National Academy of Sciences. ORCID ID: https://orcid.org/oooo-0002-7988-2805. Email: aqil.eyvazov@internet.ru

*** PhD, associate professor Azerbaijan Technical University. ORCID ID: https://orcid.org/oooo-ooo25131-3387. Email: elchin.mustafayev.80@mail.ru 


\section{Tasa de diversificación del equilibrio energético y riesgo de demanda de energía afecta al crecimiento económico: El caso de Azerbaiyán}

\section{Resumen}

El objetivo del artículo fue examinar el nivel de diversificación del balance energético y la demanda de exportación de energía, así como sus impactos en el crecimiento económico para garantizar la seguridad energética en Azerbaiyán. Para la investigación se utilizó el Índice de Demanda de Exportación de Energía Riesgo y sus cuatro subíndices, es decir, 1) dependencia de las exportaciones; 2) riesgo de monopsonio; 3) el riesgo de los costos de transacción; 4) Evaluación cuantitativa comparativa de la importancia económica de los diferentes tipos de energía en las exportaciones energéticas del país. Para la evaluación de la tasa de diversificación y concentración se utilizaron el índice de HerfindahlHirschman y el índice de Shannon-Wiener. Para evaluar la relación entre los indicadores se utilizó el método OLS, la prueba ADF y la cointegración. Se concluye que la participación de la energía obtenida de fuentes renovables en el balance energético del país es muy baja (alrededor del 3\%), y la energía obtenida de estas fuentes se utiliza principalmente para la producción de electricidad. Dado que una parte esencial del balance energético del país está en las reservas de hidrocarburos, el nivel de diversificación es bajo.

Palabras clave: balance energético; fuentes de energía renovable; seguridad energética; riesgo de demanda de exportación de energía; Azerbaiyán.

\section{Introduction}

Population growth and technical progress have led to increased energy demand globally. The disproportionate distribution of energy between countries and the increasingly rapid depletion of energy sources has made energy security a global problem. On the other hand, the use of hydrocarbons for energy production dramatically increases emissions into the environment and creates additional environmental problems. Countries are trying to use various methods, including alternative energy sources, to sustainably ensure their energy security and a healthy environment.

Studies by the International Energy Agency (IEA), multinational corporations, think tanks on energy issues show that the full use of existing oil, gas and coal deposits will lead the world to energy problems in about 40-50 years. The discovery of new resources is becoming increasingly difficult from year to year. Alternative energy sources, especially renewable energy sources (RES), are still technically imperfect or significantly more 
Shahin V. Bayramov, Gulsura Y. Mehdiyeva, Agil A. Eyvazov y Elchin R. Mustafayev

expensive for small countries, including for Azerbaijan (Gulaliyev et al., 2020a).

Azerbaijan is one of the few countries in the world that has a large amount of hydrocarbon reserves and currently does not have a serious threat to energy supply. On the contrary, Azerbaijan plays an important role in the energy supply of several European countries, Ukraine, Israel, Turkey, and Georgia. However, since the main energy reserves around the world, including in Azerbaijan, can be exhausted, the development of alternative energy sources for sustainable energy supply in the near future is important. Reducing the production of hydrocarbon reserves in order to preserve them for future generations is impossible in the existing international and geopolitical conditions, although it is consistent with the concept of sustainable development. However, a certain part of the income received from the extraction of hydrocarbon resources can be considered from an economic point of view as an investment in the development of renewable energy projects.

However, such important economic steps require serious calculations and justification of their effectiveness. First of all, it is important to find answers to several questions: 1) What is the current state of Azerbaijan's energy balance and its dynamics of the past 10-15 years? 2) How can we assess the importance of RES in the energy balance of Azerbaijan? 3) Is there any relationship between diversification or consentration rate of energy balance and economic growth? 4) Is there any relationship between energy export demand risks and economic growth?

\section{Literature review}

Four different aspects of energy security are highlighted in the economic literature. The Asia-Pacific Energy Research Center (APERC, 2019) calls these aspects: 1) availability of energy resources, 2) accessibility of energy resources, 3) environmental acceptability of the energy resources and 4) commercialization of energy resources. In studies, the presence of energy resources basically means the existence of a large number of proven natural resources. Accessibility of resources (accessibility) implies the possibility of technical extraction of natural resources for use, as well as legal opportunities for the extraction process. Environmental acceptability is related to the environmental impact of energy resources. Thus, the use of nuclear energy is a serious risk to the environment and human life. In addition, the use of coal, oil and gas is the main source of carbon dioxide emissions into the environment, which is why one of the most important political decisions is to reduce the use of these resources. Fourth, the commercialization of energy resources (affordability) refers to the risks associated with the cost of these resources. Since when energy prices are too high, new threats to energy supply arise. 
Although energy security has always been the focus of attention both at the state level and at the household level, as a global problem, they have become the center of economic research since the 1970s. The risk of using oil production as an instrument of international political pressure by oilproducing countries has caused serious concern in oil-importing countries amid growing demand for oil. Yergin (1988), who investigated the role of oil in global politics, believed that energy security was possible due to sufficient production volumes and sustainable energy supplies at a fair price. As the problem of energy security worsens, the scope of economic research in this area are also expanding, and currently the problems of supply and demand for all energy sources are the subject of research at different levels.

In their research, Cherp (2012), as well as Hughes and Phillip (2006), evaluated global energy security issues. The increasingly acute global environmental problems require the study of global energy security in the context of resolving environmental problems. Turton and Barreto (2006) believe that geopolitical development and climate change should be taken into account to ensure the long-term sustainability of the global energy system. Some authors, for example, Sovacool and Mukherjee (2011), consider that the availability of energy resources from a financial point of view, the availability of energy sources and their environmental safety are part of energy security. Muñoz et al., (2015) believe that energy security has technical, economic, social, political, environmental and geopolitical aspects.

Energy security must be quantifiable because it has different levels. Quantitative assessment of energy security in the economic literature is carried out through a separate or joint assessment of its aspects. For example, in the studies conducted by Costantini et. al., (2007) the dependence of energy security on imports was studied. As well as dependence problems on market concentration and resource availability was studied by the International Energy Agency (IEA, 2007), dependence problem on market diversification was by Stirling $(2009 ; 1998)$ identifies three main aspects of energy availability in his research as 1) a variety of categories; 2) the proportion of the distribution between the respective categories; and 3) the quantitative size of the categories. The quantitative variety of categories characterizes the number of existing and available energy resources.

Valdés (2018), Ang et al., (2015), Erahman et al., (2016), Apergis et al., (2015), Bandura (2008), Gasser (2020) and other researchers have been classified a lot of studies on energy security. Quantitative measurement of energy security and the reliability of such methods remain an important issue in research on energy security. The Herfindahl-Hirschmann Index (HHI) allows us to determine the degree of diversification in the production, consumption, and supply of energy products in any country. If the country is an energy importer, then $\mathrm{HHI}$ also allows determining the degree of dependence on 
Shahin V. Bayramov, Gulsura Y. Mehdiyeva, Agil A. Eyvazov y Elchin R. Mustafayev Diversification Rate of Energy Balance and Energy Export Demand Risk Impacts on Economic Growth: The Case of Azerbaijan

which countries for energy supply. If a country cooperates with more countries in energy supply and diversification of energy supply is higher and concentration is lower, then energy security will be higher. Thus, the weakening of the country's relations with any country that supplies it with energy will pose less of a threat to energy security. As Azerbaijan exports energy, we are more interested in the degree of diversification of the types of energy it produces. Because only one type of energy production, such as oil, can pose a threat to energy security in the future. Thus, in case of oil depletion, the country may have difficulty meeting its energy needs.

Risky External Energy Supply-REES allows you to make a comparative assessment of potential risks to energy supply in the short term. This index assumes that short-term energy import outages cannot be eliminated by the market. It is also taken into account that the intermittent supply of one energy carrier cannot be replaced by others. For this reason, the REEDI is calculated separately for each energy carrier. In this sense, REEDI differs from other energy security indices and is a non-aggregate index.

Research on the effects of energy security on economic growth is common in economic literature. For example, Balitskiy et al., (2014) studied the impact of energy security on economic growth in $26 \mathrm{EU}$ member states from 1997 to 2011. The result of this study is that there is a positive link between long-term economic growth and gas consumption. In the short term, there is a two-way cause-and-effect relationship between these two indicators. Mahmood and Ayaz (2018) explored the link between energy security and economic growth in Pakistan between 1980 and 2012. Here is the difference between supply and demand for energy, such as energy security. The result is that there is a causal link between Pakistan's energy security and economic growth, both in the long run and in the short term. The gap between energy demand and supply has a negative impact on economic growth.

There is little research on the direct effects of energy diversification and the REEDI on economic growth. However, there is a lot of research on the impact of world oil and gas prices on the economies of oil-importing and exporting countries. When world oil and gas prices change, revenues from energy exports decrease. If revenues from energy exports dominate the country's GDP, then the risk of demand for energy exports increases. On the other hand, if the degree of diversification in energy production is high, in the event of a decrease in the world price of one type of energy, the income from the export prices of another can be compensated. However, weak diversification reduces the country's energy security and increases the risk of budget revenues. These problems have been described by various researchers as the impact of oil prices on the income of the exporting country, For example, Alekhina and Yoshino (2018) in the example of European countries, Heidarian and Green (1989) in the example of Algeria, 
Al-Moneef (2006) in the example of Arab oil-exporting countries, Dreger and Rahmani (2014) on the example of the Iranian economy, Hassan and Abdullah (2014) on the example of the Sudanese economy, Olayungbo and Adediran (2017) on the example of Nigeriaç Humbatova and Hajiyev (2019) on the example of the Azerbaijani economy investigated this problem.

\section{Methodology and data}

It is important to assess the energy security of oil-exporting countries, including Azerbaijan, from three aspects. The first is a security and risk assessment aimed at supply to meet current and future demand in the country. Thus, Azerbaijani oil has been produced in large quantities over the past 150 years, and in the coming 30-40 years, it is expected to decline sharply and even pose a threat to domestic demand. However, the presence of large gas fields in the country and the expansion of the exploitation of these fields have a positive impact on the energy balance and can play an important role in ensuring energy security in the future. Second, as an oil exporter, Azerbaijan depends on the volume of demand in oil-importing countries, as well as fluctuations in oil prices on world markets.

The sharp drop in prices has a serious impact on the Azerbaijani economy. Third, are environmental risks. Thus, oil and gas production, refining, and transportation in the country have a negative impact on the environment. Taking these into account, in order to quantify energy security for Azerbaijan, it is necessary to 1) assess the diversify rate of the energy balance; 2) assess the risk to the demand of importers to Azerbaijan oil, and 3) assess the economic growth's dependence on HHI and REEDI. We will use the Herfindahl-Hirschmann and Shannon-Wiener index to assess the diversification rate of energy balance, as well as the Risky Energy Export Demand Index to assess the security connected with energy export demand.

In the general case, the energy balance can be described as a threestage system. Each stage of the energy balance can be described as a matrix consisting of several sub-stages. In some sources, for example, UN (1982), IEA (2004), Codoni et. al., (1985) these stages are characterized as the stage of "supply", "conversion" and "demand". The role of renewable energy in energy supply and consumption of the country can be understood by determining their position in the energy balance at all stages. The need to invest in the development of renewable energy sources and increase the efficiency of their use requires an assessment of the dynamics of electricity demand in the country. To assess the Herfindahl-Hirschman index we will use formule $H H \dot{I}=\sum_{i}^{\mathrm{n}} \mathrm{p}^{2}$ and to assess the Shannon-Wiener index we will use formule $S \dot{\mathrm{I}}=-\sum_{\mathrm{i}}^{\mathrm{n}} \mathrm{p}_{\mathrm{i}}{ }^{*} \ln \left(\mathrm{p}_{\mathrm{i}}\right)$. 
Shahin V. Bayramov, Gulsura Y. Mehdiyeva, Agil A. Eyvazov y Elchin R. Mustafayev 296

Diversification Rate of Energy Balance and Energy Export Demand Risk Impacts on Economic

Risky Energy Export Demand Index (REEDI), developed by Dike (2013), covers four sub-indices as a composite index. These sub-indices are 1) export dependence $(\mathrm{X})$; 2) monopsony risk $(\mathrm{M})$; 3) the risk of transaction costs (D); 4) quantitative comparative assessment of the economic importance of different types of energy in the country's energy exports (E). Dike (2013) used this index to assess the risk of demand for energy exports for 12 OPEC countries. The main assumptions for the application of this index are that the country exports oil and gas, as well as the number of exporting countries, is 3 or more. The REED index assesses current and potential risks for the short term. Azerbaijan is also an oil and gas exporter and has more than three exporting countries. Therefore, we will calculate the REED index for Azerbaijan using this method developed by Dike (2013).

The first sub-index of the REED index, i.e. the dependence of the country's economy on energy exports (X), is calculated as the ratio of energy exports to total exports. The higher this ratio, the higher the risk of the country's dependence on energy exports.

$$
X_{i}=\frac{T E E_{t}}{T E_{t}}
$$

Where $T E E_{t}$ - total energy export volume in US dollars, $\mathrm{TE}_{\mathrm{t}}$ - total export volume in US dollars.

The second sub-index of the REED index, i.e. the monopsony factor (M), is the share of the total energy exported to the energy importing country. The higher this figure, the higher the monopsony capacity of that country at the export risk of the exporting country. The HH index is used to calculate the monopsony factor $(\mathrm{M})$ :

$$
M_{t}=\sum_{i=1}^{n}\left(\frac{E E_{i t}}{T E E_{t}}\right)^{2}
$$

Where $M_{\mathrm{t}}$ - monopcony factor in t-year, $E E_{\mathrm{it}}$ - volume of energy export to the i country in t-year, $T E E_{\mathrm{t}}$ - valume of total energy export of the exporting country in t-year.

The third component of the REED index, i.e. transaction costs, includes costs that may arise as a result of disruptions in transport and infrastructure. Here, scores 1-3 are taken for transaction costs, depending on the distance between the capitals of the importing country and the exporting countries. Thus, if the distance is up to $1500 \mathrm{~km}$, transaction costs are between 1 , $1500-4000 \mathrm{~km}$, transaction costs are 2, more than $4000 \mathrm{~km}$, transaction costs are considered as 3 . The higher the transaction costs, the greater the risks. 


$$
D_{t}=\left\{\begin{array}{c}
1, \text { if distance more than } 1500 \mathrm{~km} \\
2, \text { if distance is betwenn } 1500-4000 \mathrm{~km} \\
3, \text { if distance is more than } 4000 \mathrm{~km}
\end{array}\right.
$$

The fourth sub-index of the REED index, i.e. the economic importance of exported energy sources, is calculated as the share of the export value of the energy sources (for example, oil and gas) in US dollars in the country's production:

$$
E_{t}=\frac{T E E_{t}}{G D P_{t}}
$$

Dike (2013) calculates REED index as follows:

$$
R E E D_{t}=X_{t} * M_{t} * D_{t} * E_{t}
$$

The higher $R E E D_{\mathrm{t}}$ is higher energy export demand risk of the exporter country.

To assess relationship between energy balance diversification- (or consentration-SI) rate and economic growth $\left(\mathrm{GDPG}_{\mathrm{t}}=\Delta \mathrm{GDP}_{\mathrm{t}} / \mathrm{GDP}_{\mathrm{t}-1}\right)$, as well as relationship between REEDI and economic growth will be used OLS method as follows.

$$
\left\{\begin{array}{c}
G D P G_{t}=\alpha_{0}+\alpha_{1} * H H \dot{\mathrm{I}}_{t}+\varepsilon_{t} \\
G D P G_{t}=\alpha_{0}+\alpha_{1} * S \dot{\mathrm{I}}_{t}+\delta_{t} \\
G D P G_{t}=\beta_{0}+\beta_{1} * R E E D I_{t}+v_{t}
\end{array}\right.
$$

To assess these relationships, we will adopt following hipothethis:

1. $\mathrm{H}_{\mathrm{o}}$ : There are not regration relationships between $\mathrm{GDPG}_{\mathrm{t}}$ and 1) $\mathrm{HHI}_{\mathrm{t}}$; 2) Sí $\dot{\mathrm{t}}_{\mathrm{t}}$ 3) REEDI;

2. $\mathrm{H}_{1}$ : rejecting of the $\mathrm{H}_{0}$, i.e. there are regration relationships between $\mathrm{GDPG}_{\mathrm{t}}$ and 1$) \mathrm{HHI}_{\mathrm{t}}$; 2) SI $\dot{\mathrm{I}}_{\mathrm{t}}$; 3) REEDI ;

To awoid spurious regression between these indicators we will test time series for stationarity

1. Augemented Dickey-Fuller (ADF) test for three models: a) withour intercept and trend $\left(\Delta \mathrm{y}_{\mathrm{t}}=\gamma^{*} \mathrm{y}_{\mathrm{t}-1}+\mathrm{v}_{\mathrm{t}}\right)$; b) with intercept, but without 
Shahin V. Bayramov, Gulsura Y. Mehdiyeva, Agil A. Eyvazov y Elchin R. Mustafayev

298

Diversification Rate of Energy Balance and Energy Export Demand Risk Impacts on Economic Growth: The Case of Azerbaijan

trend $\left(\Delta \mathrm{y}_{\mathrm{t}}=\alpha+\mathrm{\gamma}^{*} \mathrm{y}_{\mathrm{t}-1}+\mathrm{v}_{\mathrm{t}}\right)$; and c) with intercept and trend $\left(\Delta \mathrm{y}_{\mathrm{t}}=\alpha\right.$ $\left.+\lambda^{*} \mathrm{t}+\gamma^{*} \mathrm{y}_{\mathrm{t}-1}+\mathrm{v}_{\mathrm{t}}\right)$.

2. To test for cointegration of independent and dependent variables we will test stationarity $\varepsilon_{\mathrm{t}} ; \delta_{\mathrm{t}} ; v_{\mathrm{t}}$ from equation (1).

When checking the stationarity of time series, the values proposed in Table 1, proposed by Davidson and MacKinnon (1993), will be taken as critical values of $\tau_{c}$-tau statistics.

\begin{tabular}{|c|c|c|c|}
\hline & $1 \%$ & $5 \%$ & $10 \%$ \\
\hline$\Delta \mathbf{y}_{\mathbf{t}}=\mathbf{v}^{*} \mathbf{y}_{\mathrm{t}-1}+\mathbf{v}_{\mathbf{t}}$ & -2.56 & -1.94 & -1.62 \\
\hline$\Delta \mathbf{y}_{\mathbf{t}}=\boldsymbol{\alpha}+\mathbf{v}^{*} \mathbf{y}_{\mathrm{t}-1}+\mathbf{v}_{\mathbf{t}}$ & -3.43 & -2.86 & -2.57 \\
\hline$\Delta \mathbf{y}_{\mathbf{t}}=\mathbf{\alpha}+\lambda * \mathbf{t}+\mathbf{v}^{*} \mathbf{y}_{\mathrm{t}-1}+\mathbf{v}_{\mathrm{t}}$ & -3.96 & -3.41 & -3.13 \\
\hline Standart kritik qiymtlr & -2.33 & -1.65 & -1.28 \\
\hline
\end{tabular}

Table 1. Critical values of $\tau_{c}$-tau statistics for Dickey-Fuller testiing Source: Davidson and MacKinnon (1993)

The data used in the study on key indicators were obtained from two sources - the World Bank database (WB, 2020) and the official database of the State Statistics Committee of the Republic of Azerbaijan (SSCRA, 2020).

\section{Results}

\subsection{Energy balance dynamics of Azerbaijan}

The first component of the energy balance of any country - the total energy supply is formed by adding primary energy products to the extraction, the volume of imports and resources, and subtracting from the total volume of exports, the amounts spent on refueling international flights, including refueling ships and aircraft. The excess of exports over imports or a decrease in the share of imports in the total energy supply are important indicators of the country's energy security. That is why the World Energy Trilemma Index (WEC, 2019), calculated on the basis of energy security, environmental sustainability and energy efficiency (affordability and energy acquisition), specifically takes into account diversification of the initial energy supply, dependence on imports, etc. of countries. It is worth noting that although Azerbaijan's rating on this indicator is slightly lower than in 2017 compared to 2015 and 2016, in terms of "BBA" scores it ranks 
31st among 125 countries and is close to a number of developed countries. Azerbaijan's rating on this indicator is higher than that of some European countries and all countries of the region.

Energy security, which is the first component of the tripartite index of world energy, qualitatively assesses how efficiently the initial energy supply is regulated, as well as the ability of energy suppliers to meet current and future energy needs. Although Azerbaijan has retained a rating of "B" for this indicator over the past 3 years, its rating has slightly decreased. Energy assets, which are the second component of the tripartite index of world energy, which qualitatively assesses the availability and possibility of acquiring energy supply among the population. The indicator of Azerbaijan is also close to developed countries in this component. Since over the past three years, Azerbaijan's rating has changed from 47 points to 44 points and is constantly evaluated at the " $\mathrm{B}$ " level.

The third component of the tripartite index of world energy - $a$ sustainable environment qualitatively evaluates the efficiency of energy production on demand and supply, the possibility of producing energy supply with less carbon emissions. Azerbaijan takes 19th place among 125 countries in this component. This is a rather high indicator, and Azerbaijan has a rating of " $\mathrm{A}$ " for this indicator.

The tripartite index of world energy along with the fact that it covers almost all the key stages of the country's energy balance, also makes it possible to evaluate these stages in terms of energy security, social problems, and environmental sustainability. Therefore, the energy balance should not be regarded as a simple matrix of facts, but rather, as a database that allows you to assess social, economic, and environmental consequences and predict them.

\begin{tabular}{|c|c|c|c|c|}
\hline Iller & $\begin{array}{c}\text { Total } \\
\text { production }\end{array}$ & $\begin{array}{c}\text { Crude oil } \\
\text { (with gas } \\
\text { condensate) }\end{array}$ & $\begin{array}{c}\text { Natural } \\
\text { gas }\end{array}$ & $\begin{array}{c}\text { Renwable energy } \\
\text { sources and } \\
\text { waste }\end{array}$ \\
\hline 1995 & 641626.3 & 383552.7 & 252472 & 5601.6 \\
\hline 1996 & 626190.4 & 380998.8 & 239590 & 5601.6 \\
\hline 1997 & 612018.2 & 379784.6 & 226632 & 5601.6 \\
\hline 1998 & 696283.6 & 478300 & 212382 & 5601.6 \\
\hline 1999 & 811559.1 & 578071.5 & 227886 & 5601.6 \\
\hline 2000 & 806782.2 & 586863.8 & 214396 & 5522.4 \\
\hline 2001 & 839223.6 & 624210 & 210330 & 4683.6 \\
\hline
\end{tabular}


Shahin V. Bayramov, Gulsura Y. Mehdiyeva, Agil A. Eyvazov y Elchin R. Mustafayev

Diversification Rate of Energy Balance and Energy Export Demand Risk Impacts on Economic Growth: The Case of Azerbaijan

\begin{tabular}{|c|c|c|c|c|}
\hline 2002 & 844747.9 & 642003.9 & 195472 & 7272 \\
\hline 2003 & 847727.7 & 643971.7 & 194864 & 8892 \\
\hline 2004 & 850733.5 & 651005.5 & 189810 & 9918 \\
\hline 2005 & 1158704 & 930055.8 & 217816 & 10832.4 \\
\hline 2006 & 1704950 & 1350997 & 344888 & 9064.8 \\
\hline 2007 & $2,269,031.0$ & $1,835,057.7$ & $421,780.3$ & $12,193.0$ \\
\hline 2008 & $2,565,289.7$ & $1,917,618.6$ & $636,110.6$ & $11,560.5$ \\
\hline 2009 & $2,818,890.5$ & $2,171,866.6$ & $635,662.8$ & $11,361.1$ \\
\hline 2010 & $2,858,233.9$ & $2,190,821.4$ & $651,235.7$ & $16,176.8$ \\
\hline 2011 & $2,618,978.9$ & $1,966,215.5$ & $639,076.3$ & $13,687.1$ \\
\hline 2012 & $2,553,315 \cdot 5$ & $1,869,193.6$ & $673,476.4$ & $10,645.5$ \\
\hline 2013 & $2,583,691.9$ & $1,872,753.2$ & $698,982.6$ & $11,956.1$ \\
\hline 2014 & $2,559,924.2$ & $1,813,210.2$ & $735,363.1$ & $11,350.9$ \\
\hline 2015 & $2,557,914.5$ & $1,793,930.0$ & $751,362.1$ & $12,622.4$ \\
\hline 2016 & $2,511,579.5$ & $1,769,025 \cdot 9$ & $731,109.5$ & $11,444.1$ \\
\hline 2017 & $2,388,389.4$ & $1,667,237 \cdot 9$ & $710,345.1$ & $10,806.4$ \\
\hline 2018 & $2,434,337.5$ & $1,672,663.4$ & $750,229.3$ & $11,444.8$ \\
\hline
\end{tabular}

Table 2. Production of primary energy products (PES) (terajoule)

Note: calculated by the authors by converting "oil equvalent", metr cube" and KWh to terajoule of the SSCRA (2020) datas

Increasing of the volume of primary energy products in Azerbaijan over the past 20 years in terajoules and the preservation of relative stability ensures that there is no serious threat to energy security in the near future. Particularly, attention is paid to increasing gas production and achieving stability of the total volume in terms of a slight decreasing of crude oil production. Unfortunately, the amount of renewable energy in this volume is very small. Although the volume of RES in 2010 increased to 16,000 terajoules, the average volume of renewable energy over the past decade has been about 12,000 terajoules (Fig. 1). But this is about $0.47 \%$ of the total primary energy production (Fig. 2). 


\begin{tabular}{|c|c|}
\hline 2007000 & \\
2007000 &
\end{tabular}

The country's energy supply, as well as production capacity or the amount of exported valume of energy connected with energy security but cannot be considered as unique indicators of energy security of the country. For example, the energy security level of the countries such as Iran or Nigeria, which occupy leading positions in the export of hydrocarbon resources, is lower than in some countries with lesser resources (Sweden, Estonia, etc.). Under the current conditions of deepening globalization, greater diversification of energy supply increases the energy security level.

Since the bulk of primary energy products (crude oil and gas) are exported from Azerbaijan (approximately 75\%), the total energy supply is a small part of the volume of produced primary energy products (about 25\%). Over the past decade, imports of energy products have risen sharply. Although this volume does not have much weight in the overall energy supply, its growing dynamics and structure may threaten the country's energy security in the future. Since the bulk of imported energy products are oil products, as well as other types of gasoline and kerosene, including diesel fuel, low sulfur fuel oil, petroleum bitumen, other types of oil products, natural gas, electricity, and other types of fuel. Such import and export operations do not pose a serious threat to regional energy security. However, replacing imported gasoline with domestic products is important for a future sustainable fuel supply.

The share of RES in the total energy supply is very small (Fig. 3) and amounts to about $2 \%$, with the exception of 2010. In 2010, this figure was just over $3 \%$. For comparison, we note that the share of alternative sources and renewable energy sources in the total energy supply in Norway rich in oil exceeds 44\%, and in Australia, which is rich in hydrocarbon resources, exceeds $33 \%$. 
Shahin V. Bayramov, Gulsura Y. Mehdiyeva, Agil A. Eyvazov y Elchin R. Mustafayev

Diversification Rate of Energy Balance and Energy Export Demand Risk Impacts on Economic

\begin{tabular}{|c|c|}
\hline 0,35 & 0,035 \\
0,25 & 0,3
\end{tabular}

Crude oil is an indispensable product in the production of chemicals, which are important for various sectors of the economy. The burning of such a product to generate electricity significantly reduces the efficiency of its use. That is why in Azerbaijan, crude oil is not used for the production of heat and electricity. For the production of heat and electricity, low sulfur oil and natural gas are used. The volume of thermal and electric energy produced in the country is increasing every year. Of course, the amount of electricity is about 10 times greater than the amount of thermal energy.

The initial energy received from renewable energy is almost completely used in the transformation process. After the transformation process, the amount of energy received from RES and directed to final consumption does not have a large share in the amount of energy directed to transformation. More precisely, modern technological equipment is still not able to increase the efficiency of the renewable energy transformation process to the level of energy efficiency obtained from gas conversion. Since the efficiency for obtaining thermal and electric energy from gas for final consumption is about $33 \%$, and the coefficient of electric energy from renewable energy for final consumption does not exceed $13 \%$. 


\begin{tabular}{|c|c|}
\hline 200.000,00 & 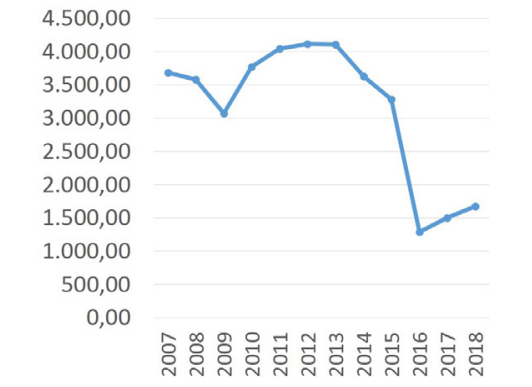 \\
\hline $\begin{array}{l}\text { Fig.5. Dynamics of final } \\
\text { consumption in the energy balance } \\
\text { of Azerbaijan (terajoule) }\end{array}$ & $\begin{array}{l}\text { Fig. 6. Volume of final } \\
\text { consumption of renewable energy } \\
\text { (terajoule) }\end{array}$ \\
\hline
\end{tabular}

Oil products, natural gas, renewable energy sources, thermal energy, electric energy and other types of fuel are used as Azerbaijan's final consumer goods. Final consumption is divided into two groups: "final consumption for energy" and "final consumption not for energy". Final consumption for energy purposes is used in such subgroups as industry and construction, transport and in other sectors of the economy. Approximately $17.1 \%$ of the energy provided for final consumption is used in subgroups of industry and construction. These industries cover areas such as ferrous metallurgy, chemical and petrochemical industries, non-ferrous metallurgy, non-metallic mineral products, transportation equipment, machinery and equipment, mining, food and tobacco, paper, pulp and printing, wood processing and production of wood products, textile, leather and clothing industry, construction, and other industries.

In $2018,28 \%$ of the energy provided for final consumption is used in the transport subgroup. This subgroup includes road transport, railway transport, inland air transport, inland water transport, pipeline transport and other modes of transport. A significant part of the energy directed to final consumption (approximately 56\%) is used in other sectors of the economy, for example, in agriculture, trade and public services, households, etc. A certain part of final consumption (approximately 13\%) is used for non-energy purposes. 
Shahin V. Bayramov, Gulsura Y. Mehdiyeva, Agil A. Eyvazov y Elchin R. Mustafayev

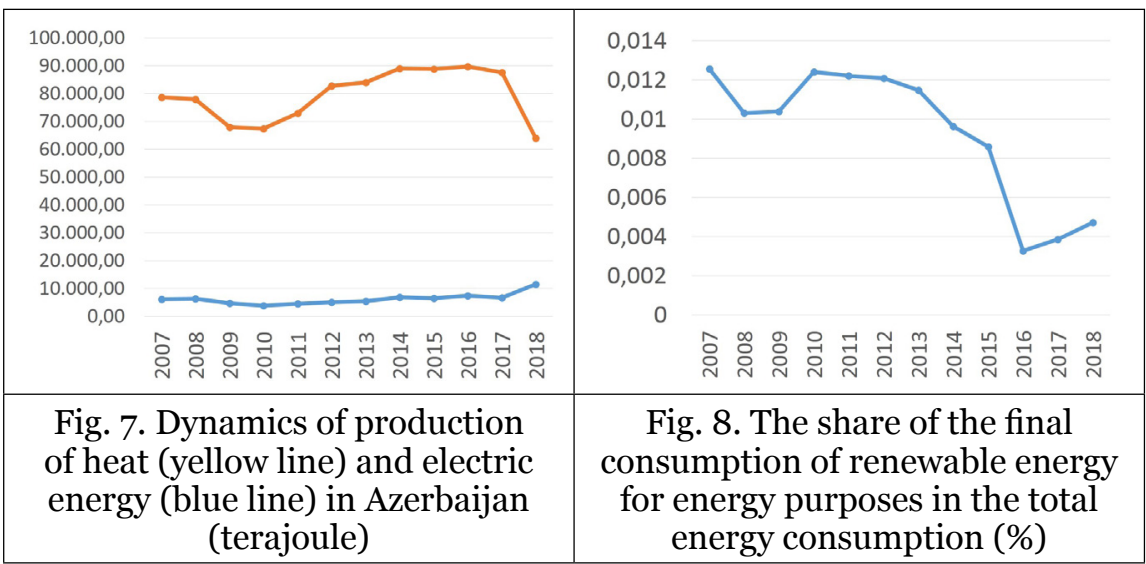

The volume of final energy consumption in Azerbaijan over the past 10 years has been continuously growing. On the other hand, the volume of use of thermal and electric energy among the types of energy directed to final consumption also grows. The share of electric energy obtained from renewable energy sources, not only has a small share in the total energy consumption, but also sharply decreased in recent years (Fig. 8). The current trend in the development of renewable energy suggests that rich oil and gas resources should not interfere with stimulating the use of renewable energy and investing in this area. Since the experience of developed countries shows that the development of renewable energy is important to ensure sustainable energy security. The main reason for the low share of renewable energy in the energy balance of oil-rich countries, of course, is the desire to get energy from hydrocarbon resources in an easier way and to abandon the additional investment in high-tech renewable energy sources. Another serious reason is that the cost of energy from renewable energy sources is still high and monopolistic electricity price is lower (Gulaliyev et al, 2020b).

\section{Energy balance diversification (or consentration) rate and Risky Energy Export Demand index of Azerbaijan}

Calculation of energy balance diversification (or energy balance concentration) rate, and energy export demand security of Azerbaijan by using HHI, SI, and REEDI consistently, gives the following results (Table 3). Over the past 20 years, all these indicators changed year by year. During 1995-2019 period HHI has a minimum score (0.512) in 1995 and maximum score (0.689) in 2007. This period SI has a minimum score (0.513) in 2007 and maximum score (0.689) in 1995. Both indices indicate that diversification is low. This also means that, despite the high level of 
energy security that is currently being ensured in Azerbaijan, the bulk of the supply of primary energy products falls on hydrocarbon reserves, which in turn may create problems in the future if these reserves are reduced. In particular, an alarming fact for energy security is that the proportion of energy from renewable energy sources in the energy balance is low. The level of diversification in the final volume of consumption is low. However, the Shannon-Wiener index in the industry is approximately two times higher than the level of diversification of primary energy production. The Herfindahl-Hirschman index can be said to not have changed fundamentally.

As Azerbaijan is rich with energy resources and there are almost no risks associated with energy supply for the near future, we believe that the main risks are related to the demand for oil and gas exports from Azerbaijan. Therefore, we accept the REED index as one of the indicators for Azerbaijan's energy security.

\begin{tabular}{|c|c|c|c|c|c|c|c|}
\hline & \multicolumn{2}{|c|}{$\begin{array}{l}\text { Diversification of } \\
\text { primary energy } \\
\text { production }\end{array}$} & \multirow{2}{*}{$\begin{array}{l}\text { Share } \\
\text { of oil } \\
\text { and gaz } \\
\text { export } \\
\text { in total } \\
\text { export- }\end{array}$} & \multirow{2}{*}{$\begin{array}{l}\text { Share } \\
\text { of oil } \\
\text { and gaz } \\
\text { export } \\
\text { in } \\
\text { GDP- }\end{array}$} & \multirow[t]{2}{*}{ Monopsony } & \multirow[t]{2}{*}{$\begin{array}{l}\text { Risky } \\
\text { Energy } \\
\text { Export } \\
\text { Demand } \\
\text { index }\end{array}$} \\
\hline & & Indeksi & Indeksi & & & & \\
\hline 1995 & - & 0.512 & 0.716 & & & & - \\
\hline 1996 & 0.041 & 0.517 & 0.712 & 66.390 & 0.132 & 0.191 & 5.012 \\
\hline 1997 & 0.247 & 0.522 & 0.707 & 61.448 & 0.121 & 0.153 & 3.412 \\
\hline 1998 & 0.122 & 0.565 & 0.659 & 68.931 & 0.094 & 0.116 & 2.256 \\
\hline 1999 & 0.030 & 0.586 & 0.633 & 78.596 & 0.159 & 0.146 & 5.475 \\
\hline 2000 & 0.151 & 0.600 & 0.618 & 85.081 & 0.282 & 0.222 & 15.935 \\
\hline 2001 & 0.083 & 0.616 & 0.596 & 91.328 & 0.370 & 0.342 & 34.669 \\
\hline 2002 & 0.093 & 0.631 & 0.588 & 88.922 & 0.309 & 0.270 & 22.255 \\
\hline 2003 & 0.167 & 0.630 & 0.595 & 86.011 & 0.306 & 0.289 & 22.867 \\
\hline 2004 & 0.193 & 0.635 & 0.591 & 82.216 & 0.342 & 0.223 & 18.863 \\
\hline 2005 & 0.526 & 0.680 & 0.534 & 76.765 & 0.443 & 0.124 & 12.690 \\
\hline 2006 & 0.584 & 0.669 & 0.535 & 84.591 & 0.525 & 0.227 & 30.233 \\
\hline 2007 & 0.575 & 0.689 & 0.513 & 81.399 & 0.524 & 0.085 & 10.878 \\
\hline 2008 & 0.478 & 0.620 & 0.588 & 97.083 & 0.608 & 0.193 & 34.216 \\
\hline 2009 & -0.093 & 0.644 & 0.559 & 92.857 & 0.442 & 0.108 & 13.274 \\
\hline 2010 & 0.194 & 0.639 & 0.570 & 94.509 & 0.473 & 0.139 & 18.575 \\
\hline
\end{tabular}


Shahin V. Bayramov, Gulsura Y. Mehdiyeva, Agil A. Eyvazov y Elchin R. Mustafayev 306

Diversification Rate of Energy Balance and Energy Export Demand Risk Impacts on Economic Growth: The Case of Azerbaijan

\begin{tabular}{|l|l|r|r|r|r|r|r|}
\hline 2011 & 0.247 & 0.623 & 0.587 & 94.747 & 0.496 & 0.161 & 22.650 \\
\hline 2012 & 0.057 & 0.606 & 0.603 & 93.419 & 0.437 & 0.090 & 10.977 \\
\hline 2013 & 0.064 & 0.599 & 0.612 & 92.985 & 0.397 & 0.099 & 11.002 \\
\hline 2014 & 0.015 & 0.584 & 0.627 & 92.638 & 0.348 & 0.087 & 8.381 \\
\hline 2015 & -0.295 & 0.578 & 0.635 & 88.285 & 0.276 & 0.075 & 5.463 \\
\hline 2016 & -0.287 & 0.581 & 0.631 & 91.541 & 0.317 & 0.131 & 11.399 \\
\hline 2017 & 0.079 & 0.576 & 0.636 & 91.119 & 0.345 & 0.146 & 13.733 \\
\hline 2018 & 0.153 & 0.567 & 0.646 & 92.222 & 0.397 & 0.119 & 13.047 \\
\hline 2019 & 0.020 & & & 91.239 & 0.380 & 0.123 & 12.740 \\
\hline
\end{tabular}

Table 3. Dynamics of Economic groüthç Energy balance diversification rate and Risky Energy Export Demand index of Azerbaijan

Note: calculated by the authors

\section{Impacts of energy balance diversification rate and energy export demand on economic growth}

The regression relationship between the rate of diversification (or concentration) of the production component of the energy balance calculated by HHI and SI shows that there is a significant relationship between these indicators. Calculations show that there is a similar relationship between economic growth and the Risky Energy Demand (REED) index (Table 4). Thus, an increase in the degree of diversification has a positive effect on economic growth, and an increase in the degree of concentration has a negative effect. The Risky Energy Export Demand Index is also positively related to economic growth. This means that the restriction of the number of importing countries of Azerbaijan oil and gas resources (monopsony), the sharp increase in the share of oil and gas in export and GDP amount have positive impacts on economic growth, but also threatens the country's energy security and increases the REEDI.

\begin{tabular}{|c|c|c|c|}
\hline & HHI $_{t}$ & S $_{t}$ & REEDI $_{t}$ \\
\hline $\mathrm{R}^{2}$ & 0.299645 & 0.27067 & 0.169602 \\
\hline Observation & 23 & 23 & 24 \\
\hline F-significance & 0.006861 & 0.010931 & 0.045546 \\
\hline$\alpha_{0}$ & \multicolumn{3}{|l}{} \\
\hline coefficient & -1.57996 & 1.626039 & -0.01067 \\
\hline
\end{tabular}


CUESTIONES POLÍTICAS

Vol. 39 N $^{0} 68$ (Enero - Junio 2021): 290-314

\begin{tabular}{|c|c|c|c|}
\hline Standart deviation & 0.578223 & 0.530787 & 0.084521 \\
\hline t-statistics & -2.73244 & 3.063449 & -0.12626 \\
\hline $\mathrm{p}$-value & 0.012478 & 0.005899 & 0.900676 \\
\hline \multicolumn{4}{|l|}{$\alpha_{1}$} \\
\hline coefficient & 2.848825 & -2.43149 & 0.010278 \\
\hline Standart deviation & 0.950411 & 0.870972 & 0.004849 \\
\hline t-statistics & 2.997466 & -2.79169 & 2.119746 \\
\hline p-value & 0.006861 & 0.010931 & 0.045546 \\
\hline
\end{tabular}

Table 4. Relationship between $\mathrm{HHI}_{\mathrm{t}}$ (or Si $\dot{\mathrm{I}}_{\mathrm{t}}$ ), REEDI $\dot{\mathrm{I}}_{\mathrm{t}}$, and economic growth

Note: calculated by the authors

To be sure that these relationships are not spurious we need to test the stationarity of the GDPG $, \mathrm{HHI}_{t}, \mathrm{SI}_{\mathrm{t}}$ and REEDI ${ }_{t}$ and time series or to test cointegration between independent and dependent variables.

Stationarity of the GDPG, $\mathrm{HH}_{\boldsymbol{t}}, \boldsymbol{S I}$, and $R E E D \dot{I}_{t}$ time series (ADF test)

Note that the maximum lag $=5$ will be taken to check the stationarity of the time series of these indicators. As a method, the least-squares method (OLS) is selected, and the Schwartz information criterion is used. The hypothesis $\mathrm{H}_{0}$ for the time series of the indicators is existing of a unit root. The $\mathrm{H}_{1}$ hypothesis is the rejection of $\mathrm{H}_{\mathrm{o}}$, that is, the time series does not have a single root. The results of the analysis conducted using the E-Views software package are given in Table 5 . It can be seen from the table 5 that none of the time series is stationary in for models.

\begin{tabular}{|c|c|c|c|c|c|c|c|}
\hline \multicolumn{7}{|c|}{ No intercept, no trend $\left(\Delta \mathrm{y}_{\mathrm{t}}=\beta^{*} \mathrm{y}_{\mathrm{t}-1}+\mathrm{v}_{\mathrm{t}}\right)$} \\
\hline & $\begin{array}{c}\mathrm{R}- \\
\text { squared }\end{array}$ & coefficient & Std. error & $\begin{array}{c}\mathrm{t}- \\
\text { statistics }\end{array}$ & probability & $\begin{array}{c}\text { Mac- } \\
\text { Kinnon } \\
\text { one sided } \\
\text { p-value }\end{array}$ \\
\hline $\begin{array}{c}\text { GDPG } \\
\text { (t) }\end{array}$ & $\begin{array}{c}\text { GDPG } \\
\text { (t-1) }\end{array}$ & 0.137694 & -0.275040 & 0.146732 & -1.874437 & 0.0742 & 0.0592 \\
\hline
\end{tabular}


Shahin V. Bayramov, Gulsura Y. Mehdiyeva, Agil A. Eyvazov y Elchin R. Mustafayev

308

Diversification Rate of Energy Balance and Energy Export Demand Risk Impacts on Economic Growth: The Case of Azerbaijan

\begin{tabular}{|c|c|c|c|c|c|c|c|}
\hline HHİ & $\begin{array}{c}\text { HHİ } \\
(\mathrm{t}-1)\end{array}$ & -0.005514 & 0.002805 & 0.007984 & 0.351343 & 0.7287 & 0.7780 \\
\hline Sİ & Sİ (t-1) & 0.009369 & -0.006399 & 0.008848 & -0.723188 & 0.4772 & 0.3922 \\
\hline REEDI் & $\begin{array}{c}\text { REEDI் } \\
(\mathrm{t}-1)\end{array}$ & 0.352115 & -0.065425 & 0.114416 & -0.571819 & 0.5738 & 0.4579 \\
\hline
\end{tabular}

\begin{tabular}{|c|c|c|c|c|c|c|c|}
\hline \multicolumn{8}{|c|}{ With intercept, no trend $\left(\Delta \mathrm{y}_{\mathrm{t}}=\alpha+\beta * \mathrm{y}_{\mathrm{t}-1}+\mathrm{v}_{\mathrm{t}}\right)$} \\
\hline & & $\begin{array}{c}\text { R- } \\
\text { squared }\end{array}$ & coefficient & Std.error & $\begin{array}{c}\mathrm{t}- \\
\text { statistics }\end{array}$ & probability & $\begin{array}{c}\text { Mac- } \\
\text { Kinnon } \\
\text { one sided } \\
\text { p-value }\end{array}$ \\
\hline \multirow[t]{2}{*}{$\begin{array}{c}\text { GDPG } \\
(\mathrm{t})\end{array}$} & $\begin{array}{c}\text { GDPG } \\
(\mathrm{t}-1)\end{array}$ & \multirow[t]{2}{*}{0.195392} & 0.392902 & 0.173986 & -2.258246 & 0.0347 & \multirow[t]{2}{*}{0.1929} \\
\hline & $\mathrm{C}$ & & 0.057578 & 0.046920 & 1.227155 & 0.2333 & \\
\hline \multirow[t]{2}{*}{ HHİ } & $\begin{array}{l}\mathrm{HHI} \\
(\mathrm{t}-1)\end{array}$ & \multirow[t]{2}{*}{0.153489} & -0.189842 & 0.097288 & -1.951339 & 0.0645 & \multirow[t]{2}{*}{0.3046} \\
\hline & $\mathrm{C}$ & & 0.117139 & 0.058980 & 1.986079 & 0.0602 & \\
\hline \multirow[t]{2}{*}{ Sİ } & Sİ (t-1) & \multirow[t]{2}{*}{0.165144} & -0.197806 & 0.097052 & -2.038148 & 0.0543 & \multirow[t]{2}{*}{0.2697} \\
\hline & $\mathrm{C}$ & & 0.117747 & 0.059484 & 1.979491 & 0.0610 & \\
\hline \multirow[t]{3}{*}{ REEDİ } & $\underset{(\mathrm{t}-1)}{\mathrm{REEDI}}$ & \multirow[t]{3}{*}{0.476233} & -0.534506 & 0.244970 & -2.181922 & 0.0419 & \multirow[t]{3}{*}{0.2177} \\
\hline & $\begin{array}{c}\mathrm{D} \\
(\mathrm{REED} \\
(\mathrm{t}-1)\end{array}$ & & -0.330260 & 0.203399 & -1.623700 & 0.1209 & \\
\hline & $\mathrm{C}$ & & 8.859835 & 4.175423 & 2.121901 & 0.0472 & \\
\hline
\end{tabular}

\begin{tabular}{|c|c|c|c|c|c|c|c|}
\hline \multicolumn{8}{|c|}{ With intercept and trend $\left(\Delta y_{t}=\alpha+\lambda * t+\beta * y_{t-1}+v_{t}\right)$} \\
\hline & & $\begin{array}{c}\text { R- } \\
\text { squared }\end{array}$ & coefficient & Std.error & $\begin{array}{c}\mathrm{t}- \\
\text { statistics }\end{array}$ & probability & $\begin{array}{c}\text { Mac- } \\
\text { Kinnon } \\
\text { one-sided } \\
\text { p-value }\end{array}$ \\
\hline \multirow[t]{3}{*}{$\begin{array}{c}\text { GDPG } \\
(\mathrm{t})\end{array}$} & $\begin{array}{c}\text { GDPG } \\
(\mathrm{t}-1)\end{array}$ & \multirow[t]{3}{*}{0.240454} & -0.444174 & 0.179499 & -2.474519 & 0.0224 & \multirow[t]{3}{*}{0.3361} \\
\hline & & & 0.144750 & 0.092663 & 1.562120 & 0.1339 & \\
\hline & & & -0.006628 & 0.006085 & -1.089287 & 0.2890 & \\
\hline \multirow[t]{3}{*}{ HHİ } & $\underset{(\mathrm{t}-1)}{\mathrm{HHI}}$ & \multirow[t]{3}{*}{0.265847} & -0.136742 & 0.097675 & - 1.399978 & 0.1768 & \multirow[t]{3}{*}{0.8334} \\
\hline & $\mathrm{C}$ & & 0.099487 & 0.057180 & 1.739898 & 0.0972 & \\
\hline & trend & & -0.001204 & 0.000688 & -1.749538 & 0.0955 & \\
\hline
\end{tabular}




\begin{tabular}{|c|c|c|c|c|c|c|c|}
\hline \multirow[t]{3}{*}{ Sİ } & $\underset{(t-1)}{S \dot{I}}$ & \multirow[t]{3}{*}{0.249166} & -0.138972 & 0.102183 & -1.360035 & 0.1890 & \multirow[t]{3}{*}{0.8454} \\
\hline & $\mathrm{C}$ & & 0.067300 & 0.066921 & 1.005659 & 0.3266 & \\
\hline & trend & & 0.001210 & 0.000809 & 1.496027 & 0.1503 & \\
\hline \multirow[t]{3}{*}{ REEDİ } & $\underset{(\mathrm{t}-1)}{\mathrm{SI}}$ & \multirow[t]{3}{*}{0.375243} & -0.708931 & 0.206834 & -3.427531 & 0.0027 & \multirow[t]{3}{*}{0.0722} \\
\hline & $\mathrm{C}$ & & 12.56449 & 4.934908 & 2.546042 & 0.0192 & \\
\hline & trend & & -0.127067 & 0.282463 & -0.449854 & 0.6577 & \\
\hline
\end{tabular}

Table 5. Stationarity $\mathrm{GDPG}_{\mathrm{t}}, \mathrm{HH} \dot{\mathrm{I}}_{\mathrm{t}}, \mathrm{SI}_{\mathrm{t}}$ and REEDI $\dot{\mathrm{t}}_{\mathrm{t}}$ time series

Note: calculation by the authors

Thus, Table 5 shows that $\boldsymbol{G D P G}, \boldsymbol{H H}_{\boldsymbol{t}}$ and $\boldsymbol{S I}_{\boldsymbol{t}}$ time series are not stationary for all three models. REEDI time series is stationary only in case of "with trend and intercept" but only by $10 \%$ significance. It should be noted that the fact that the time series characterizing the indicators involved in the study are not stationary does not mean that the regression relationship between them is "spurious". Thus, if the $\varepsilon_{\text {it }}$ residues in the regression relationship between these indicators is stationary, then the regression relationship can be approached as a "truth" relationship, as stationarity of $\varepsilon_{\text {it }}$ indicates co-integration of the independent and dependent variables. Therefore, we will need to check the stationarity of the $\varepsilon_{\text {it }}$ residues in each pair of regression relationships from the equation (1).

We will test stationarity of $\varepsilon_{\text {it }}$ residual time series where $\varepsilon_{\text {it }}$ can be estimated by three models as following

$$
\begin{gathered}
\text { 1) } \hat{\varepsilon} \hat{i t}=y_{i t}-b^{*} x_{i t} \text {; } \\
\text { 2) } \hat{\varepsilon}{ }_{i t}=y_{i t}-b^{*} x_{i t}-c ; \\
\text { 3) } \hat{\varepsilon_{i t}}=y_{i t}-b^{*} x_{i t}-c-\delta * t
\end{gathered}
$$

And we will apply ADF test for

$$
\hat{\varepsilon_{\text {it }}}=\boldsymbol{\gamma}^{*} \hat{\varepsilon_{\mathrm{t}-1}}+\mathbf{v}_{\mathrm{t}}
$$

For stationarity $\varepsilon_{\text {it }}$ residual time series according to equation (2) we will use MacKinnon critical value as in the Table 8. 
Shahin V. Bayramov, Gulsura Y. Mehdiyeva, Agil A. Eyvazov y Elchin R. Mustafayev

\begin{tabular}{|l|c|c|c|}
\hline & $1 \%$ & $5 \%$ & $10 \%$ \\
\hline 1) $\mathbf{y}_{\mathbf{t}}=\boldsymbol{\beta} * \mathbf{x}_{\mathbf{t}}+\boldsymbol{\varepsilon}_{\mathbf{t}}$ & -3.39 & -2.76 & -2.45 \\
\hline 2) $\mathbf{y}_{\mathbf{t}}=\boldsymbol{\beta}_{\mathbf{1}}+\boldsymbol{\beta}_{\mathbf{2}}{ }^{*} \mathbf{x}_{\mathbf{t}}+\boldsymbol{\varepsilon}_{\mathbf{t}}$ & -3.96 & -3.37 & -3.07 \\
\hline 3) $\mathbf{y}_{\mathbf{t}}=\boldsymbol{\beta}_{\mathbf{1}}+\boldsymbol{\delta}{ }^{*} \mathbf{t}+\boldsymbol{\beta}_{\mathbf{2}}{ }^{*} \mathbf{x}_{\mathbf{t}}+\boldsymbol{\varepsilon}_{\mathbf{t}}$ & -3.98 & -3.42 & -3.13 \\
\hline
\end{tabular}

Table 8. Critical values for cointegration $\left(\tau_{c}\right)$

Source: Davidson and MacKinnon (1993)

As we will use equation $y_{t}=\beta_{1}+\beta_{2}^{*} x_{t}+\varepsilon_{t}$ for critical values of $\tau_{c}$ will be (-3.96) for $1 \%,(-3.37)$ for $5 \%$ and $(-3.07)$ for $10 \%$ significance.

Testing of residuals stationarity by ADF show that there are cointegration between 1) $\mathrm{GDPG}_{t}$ and $\mathrm{HHI}_{t}$; 2) GDPG and $\mathrm{SI}_{t}$; 3) GDPG and REEDİ. But cointegration between $\mathrm{GDPG}_{\mathrm{t}}-\mathrm{HHI}^{\mathrm{t}}{ }^{\prime}$ and $\mathrm{GDPG}_{-}-\mathrm{SI}_{\mathrm{t}}$ has $5 \%$ significance, and cointegration between $\mathrm{GDPG}_{\mathrm{t}}-$ REEDI $_{t}$ has $10 \%$ significance (Table 9).

\begin{tabular}{|c|c|c|c|}
\hline & $\mathrm{GDP}_{\mathrm{t}}-\mathrm{HHI}_{\mathrm{t}}$ & $\mathrm{GDP}_{\mathrm{t}}-\mathrm{SI}_{\mathrm{t}}$ & $\mathrm{GDP}_{\mathrm{t}}-\mathrm{REEDI}_{\mathrm{t}}$ \\
\hline \multicolumn{4}{|l|}{$\widehat{\varepsilon_{i t}}=\gamma^{*} \hat{\varepsilon_{t-1}}+v_{t}$} \\
\hline \multirow[t]{2}{*}{ R-squared } & 0.312023 & 0.299978 & 0.227594 \\
\hline & -0.618788 & -0.592882 & -0.461068 \\
\hline Std.error & 0.200490 & 0.197601 & 0.180898 \\
\hline t-statistcs & -3.086374 & -3.000404 & -2.548773 \\
\hline probability & 0.0056 & 0.0068 & 0.0183 \\
\hline $\begin{array}{l}\text { Mackinnon one - } \\
\text { sided p-value }\end{array}$ & 0.0037 & 0.0045 & 0.0133 \\
\hline
\end{tabular}

Table 9. Stationarity of $\varepsilon_{\text {it }}$ residuals time series by ADF tests Note: calculated by the authors

\section{Discussion}

As one of the rich countries with oil and gas resources, as well as one of the countries whose exports and revenues are mainly related to energy exports, in Azerbaijan, the nature of the impacts of energy diversification rate and the risk to energy exports demand on economic growth are consistent with the impact of oil and gas revenues on macroeconomic 
indicators. Thus, in the studies conducted by Alekhina and Yoshino (2018), Hassan and Abdullah (2014), Olayungbo and Adediran (2017), rising of oil prices (that is, increasing in energy demand on the world market) has a positive effect on economic growth by increasing the country's oil revenues.

\section{Conclusions}

Azerbaijan is relatively rich in energy resources. Also, stability has been observed in the production and export of primary energy products over the past decades. All this indicates that the country's energy security in the short term is ensured. In the coming years, gas production will increase, while oil production will decrease - this will prevent a significant reduction in the energy balance. Unfortunately, the share of energy received from renewable energy sources in the country's energy balance is small (about $3 \%)$. At the same time, the energy obtained from these sources is used mainly for the production of electricity. Given the fact that the bulk of the country's energy balance is hydrocarbons, the level of diversification is low. For this reason, future reductions in hydrocarbon reserves could jeopardize the country's energy security. As a result, we conclude that in order to ensure energy security it is necessary to develop renewable energy sources. There is positive relationship between energy security and economic growth in Azerbaijan. Thus, increasing energy security is stimulating economic growth.

\section{Bibliographic References}

ALEKHINA, Victoriia; YOSHINO, Naoyuki. 2018. "Impact of World Oil Prices on an Energy Exporting Economy Including Monetary Policy. ADBI Working Paper 828” In: Asian Development Bank Institute. Available online. In: https://www.adb.org/publications/impact-world-oil-pricesenergy-exporting-economy-including-monetary-policy. Consultation date: $26 / 12 / 2019$.

AL-MONEEF, Majid. 2006. The Contribution of the Oil Sector to Arab Economic Development. Roundtable. Available online. In: http:// www.adelinotorres.info/mediooriente/arabes_petroleo_e_ desenvolvimento_dos_paises_arabes.pdf. Consultation date: 26/12/2019.

ANG, Beng W; CHOONG, Wei Lim; NG, Tsan Sheng. 2015. "Energy security: Definitions, dimensions and indexes" In: Renewable and Sustainable Energy Reviews. Available online. In: https://doi.org/10.1016/j. rser.2014.10.064. Consultation date: 26/12/2019. 
Shahin V. Bayramov, Gulsura Y. Mehdiyeva, Agil A. Eyvazov y Elchin R. Mustafayev

APERC. 2019. Asia Pacific Energy Research Centre. Available online. In: https://aperc.or.jp/. Consultation date: 26/12/2019.

APERGIS, Nicholas; AYE, Goodness; BARROS, Carlos; GUPTA, Rangan; WANKE, Peter. 2015. "Energy efficiency of selected OECD countries: a slacks-based model with undesirable outputs" In: Energy Econ. Available online. In: https://doi.org/10.1016/j.eneco.2015.05.022. Consultation date: 26/12/2019.

BALITSKIY, Sergey; BILAN, Yuriy; STRIELKOWSKI, Wadim. 2014. "Energy security and economic growth in the European union" In: Journal of Security and Sustainability. Issues 4, No. 2, pp. 123-130.

BANDURA, Romina. 2008. A Survey of Composite Indices Measuring Country Performance: 2008 Update. United Nations Development Programme, Office of Development Studies (UNDP/ODS Working Paper). New York, USA.

CHERP, Aleh. 2012. Global Energy Assessment-Toward a Sustainable Future. Cambridge University Press and the International Institute for Applied Systems Analysis. Cambridge, UK, Laxenburg, Austria.

CODONI, Rene; PARK, Hi-Chun, RAMANI, KV (eds). 1985. Integrated energy planning: a manual. Asian and Pacific Development Centre. Kuala Lumpur, Malaysia.

COSTANTINI, Valeria; GRACCEVA, Francesco; MARKANDYA, Anil; VICINI, Giorgio. 2007. "Security of energy supply: Comparing scenarios from a European perspective” In: Energy Policy. Vol. 35, Issue 1, pp. 210-226.

DAVIDSON, Russell; MACKINNON, James G. 1993. Estimation and İference in Econometrics. Oxford University Press. New York, USA. p. 708.

DIKE, Jude Chukwudi. 2013. "Measuring the security of energy exports demand in OPEC economies" In: Energy Policy. Vol 60, pp. 594-600.

DREGER, Christian; RAHMANI, Teymur. 2014. The Impact of Oil Revenues on the Iranian Economy and the Gulf States, IZA Discussion Papers, No. 8079, Institute for the Study of Labor (IZA). Bonn, Germany.

ERAHMAN, Qodri Febrilian; PURWANTO, Widodo Wahyu; SUDIBANDRIYO, Mahmud; HIDAYATNO, Akhmad. 2016. "An assessment of Indonesia's energy security index and comparison with seventy countries" In: Energy. Available online. In: https://doi.org/10.1016/j.energy.2016.05.100. Consultation date: $26 / 12 / 2019$.

GASSER, Patrick. 2020. "A review on energy security indices to compare country performances” In: Energy Policy. Vol. 139. Pp. 111-339. 
GULALIYEV, Mayis. G; MUSTAFAYEV, Elchin. R; MEHDIYEVA, Gulsura. Y. 2020a. "Assessment of Solar Energy Potential and Its EcologicalEconomic Efficiency: Azerbaijan Case" In: Sustainability. Available online. In: https://doi.org/10.3390/su12031116. Consultation date: 05/05/2020.

GULALIYEV, Mayis; YUZBASHIYEVA, Gulsen; MAMEDOVA, Gulnara; ABASOVA, Samira; SALAHOV, Fariz; ASKEROV, Ramil. 202ob. "Consumer Surplus Changing in the Transition from State Natural Monopoly to the Competitive Market in the Electricity Sector in the Developing Countries: Azerbaijan Case" In: International Journal of Energy Economics and Policy. Vol 10, No 2, pp. 265-275.

HASSAN, Khalid; ABDULLAH, Azrai. 2014. Effect of Oil Revenue and the Sudan Economy: Econometric Model for Services Sector GDP. Global Conference on Business \& Social Science-2014, GCBSS-2014, 15th \& 16th December. Kuala Lumpur, Malaysia.

HEIDARIAN, Jamshid; GREEN, Rodney D. 1989. "The impact of oil-export dependency on a developing country the case of Algeria" In: Energy Economics. Vol. 11, Issue 4, pp. 247-261.

HUGHES, Llewelyn; PHILLIP, Y. Lipscy. 2006. "The politics of energy" In: Ann. Rev. Political Sci. Vol 16. Pp. 449-469.

HUMBATOVA, Sugra Ingilab; HAJIYEV, Natig Qadim-Oglu. 2019. Oil Factor in Economic Development. Energies. Available online. In: https://doi. org/10.3390/en12081573. Consultation date: 05/05/2020.

IEA. 2004. "Energy statistics manual” In: International Energy Agency. Paris, France.

IEA. 2007. Climate Policy and Energy Security. Available online. In: https:// www.iea.org/reports/energy-security-and-climate-policy. Consultation date: 19/12/2019.

MAHMOOD, Tahir; AYAZ, Muhammed Tayyab. 2018. "Energy security and economic growth in Pakistan" In: Pakistan Journal of Applied Economics. Vol 28 No.1, pp. 47-64

MUÑOZ, Beatriz; GARCÍA-VERDUGO, Javier; SAN-MARTÍN, Enrique. 2015. "Quantifying the geopolitical dimension of energy risks: A tool for energy modelling and planning" In: Energy. Vol 82, pp. 479-500.

OLAYUNGBO, D. Oluseun; ADEDIRAN, Kazeem A. 2017. "Effects of Oil Revenue and Institutional Quality on Economic Growth with an ARDL Approach” In: Energy and Policy Research. Available online. In: 
Shahin V. Bayramov, Gulsura Y. Mehdiyeva, Agil A. Eyvazov y Elchin R. Mustafayev

314

Diversification Rate of Energy Balance and Energy Export Demand Risk Impacts on Economic

https://doi.org/10.1080/23815639.2017.1307146. Consultation date: 19/12/2019.

SOVACOOL, Benjamin K; MUKHERJEE, Ishani. 2011. "Conceptualizing and measuring energy security: A synthesized approach” In: Energy. Vol. 36, No. 8, pp. 5343-5355.

SSCRA. 2020. Available online. In: https://www.stat.gov.az/source/balance fuel/. Consultation date: 19/08/2020.

STIRLING, Andy. 1998. On the Economics and Analysis of Diversity. SPRU Electronic Working Paper Series. Paper No. 28.

STIRLING, Andy. 2009. "Multicriteria diversity analysis: A novel heuristic framework for appraising energy portfolios" Available online. In: https:// doi.org/10.1016/j.enpol.2009.02.023. Consultation date: 19/12/2019.

TURTON, Hal; BARRETO, Leonardo. 2006. "Long-term security of energy supply and climate change" In: Energy Policy. Volume 34, Issue 15, pp. 2232-2250.

UN. 1982. Concepts and methods in energy statistics, with special reference to energy accounts and balances: a technical report. Series F No. 29, Department of International Economic and Social Affairs. Available online. In: https://unstats.un.org/unsd/publication/SeriesF/ SeriesF_29E.pdf. Consultation date: 19/12/2019.

VALDÉS, Javier. 2018. "Arbitrariness in Multidimensional Energy Security Indicators" In: Ecological Economics. Available online. In: https://doi. org/10.1016/j.ecolecon.2017.09.002. Consultation date: 19/12/2019.

WB. 2020. World Bank Open data. Available online. In: https://data.worldbank. org. Consultation date: 19/12/2019.

WEC. 2019. World Energy Council. Available online. In: https://trilemma. worldenergy.org. Consultation date: 19/12/2019.

YERGIN, Daniel. 1988. "Energy security in the 1990s" In: Council on Foreign Relations. Vol. 67, No. 1, pp. 110-132. 
ISSN 0798-1406 Depósito legal pp 198502ZU132

\section{Cuestiones Políticas}

\section{Planilla de suscripción}

Nombre

Institución

Dirección

Ciudad País

Cheque de gerencia a nombre de: Universidad del Zulia (LUZ),

Facultad de Ciencias Jurídicas y Políticas, Ingresos Propios

Banco Occidental de Descuento, Cuenta corriente № 212700890-9

Tarifa de suscripción por un año (dos números):

Venezuela: Bs. 80 + Envío

Ejemplar solo: Bs. $40+$ Envío

América Latina \$ $40+$ Envío

Resto del mundo $\$ 50+$ Envío

Esta planilla debe ser enviada a la siguiente dirección:

Revista "Cuestiones Políticas"

Facultad de Ciencias Jurídicas y Políticas

Instituto de Estudios Políticos y Derecho Público

Apartado Postal 526, Maracaibo Venezuela

Puede adelantar información por: cuestionespoliticas@gmail.com

loichirinosportillo@gmail.com 